\title{
Professor A.L. Nagar's Glorious Academic Life at The Delhi School of Economics and Elsewhere: An Introductory Essay
}

\author{
K. L. Krishna ${ }^{1}$
}

Accepted: 27 October 2021 / Published online: 14 December 2021

(c) The Author(s), under exclusive licence to The Indian Econometric Society 2021

\section{Introduction}

Prof. A.L Nagar (1930-2014) played several important roles in the Department of Economics, Delhi School of Economics (DSE) as a teacher, researcher, research supervisor, Head of the Department and Director of the School, Pro-Vice Chancellor, Delhi University, 1990-1995, acting Vice-Chancellor (VC) Delhi University for eight months in 1995, during his service in the University of Delhi, from 1963 to 1995. Subsequently, he was a Visiting Professor in Jawahar Lal Nehru University (JNU) and Honorary Senior Consultant at National Institute of Public Finance and Policy (NIPFP) and Visiting Fellow at ISPE (Indian School of Political Economy), Pune. This introductory essay seeks to provide an account of the major academic activities of Prof. Nagar, in his life time. It also covers his contributions to the Indian Econometric Society (TIES) in his capacity as President during 1976-81, succeeding Prof. C.R. Rao. He was Editor-in-Chief of the Society's journal, Journal of Quantitative Economics (JQE), during 1984-2014.

The plan of the essay is as follows. Section 2 is based on Kumar and Mookherjee (1995), D. School: Reflections on The Delhi School of Economics, covering the period 1949 to early 1990s, and Krishna (2017), which extends the period coverage to mid-2010s. Section 3 describes Prof Nagar's academic activities at JNU, NIPFP and ISPE. The essay ends with Sect. 4: concluding remarks.

\section{K. L. Krishna}

krishna@econdse.org

1 Centre for Development Economics, Delhi School of Economics, Delhi, India 


\section{Delhi School of Economics (DSE)}

\section{Towards Founding of DSE-1942-1949}

Prof V K R V Rao, Founder of the DSE, pursued higher studies in Economics in Cambridge, U.K., where he stood first in the Economics Tripos and won the Adam Smith Prize. He was among the first three Ph.Ds Cambridge produced in Economics. He believed in the economic profession playing a major role in public policy for economic development. After his return to India from Cambridge in 1937, Rao taught in Andhra University and Karnataka University between 1937 and 1942. Maurice Gwyer, VC, Delhi university, appointed Rao as the first professor of Economics in 1942. By 1946, Rao made up his mind to establish DSE on the lines of LSE. He sought the help of Dr. B N Ganguly and Mr. P N Dhar, two teachers in Hindu College, Delhi. Thanks to Rao's dynamism and oratorical skills, and writings on the country's economic development prospects, he came into contact with Prime Minister Nehru, at the time of Indian independence. The DSE Society with Nehru as the President got formally registered in 1949, and thus the year of birth of DSE is taken as 1949. The DSE grew out of the Department of Economics of Delhi University.

\section{9-1962- Major Developments at DSE}

The expansion of the School began in 1953 after its shifting from barracks to the Arts Faculty building with ample space. Considerable additions were made to the academic and administrative staff. A statistical unit was established and a number of research assistants and research fellows were recruited. The Indian Economic Review, journal of DSE, was launched in 1952. The most note- worthy appointment was that of Dr. K N Raj as Professor of Monetary Economics in 1953. Raj came from the Planning Commission after his assignment in connection with the First Five Year Plan (1951-1956) ended. His wide interests, affability and scholarship endeared Raj to colleagues and students, as noted by Dhar (1995).

Rao wanted the School to have its own building and a campus. He secured from the University a nine-acre plot of land. A donation of Rs. six lakhs from the Birla Educational Trust for the building and Rs.one lakh from Lady Ratan Tata for the library were obtained and construction was undertaken. The main building (Birla Bhawan) of the School was inaugurated in 1956 by Prime Minister Nehru. Prof Rao was appointed as VC in 1957. Prof B N Ganguly, Professor of International Trade, succeeded him as Director of DSE. In 1959, Prof Rao as VC took the initiative to establish the university departments of Sociology and Human Geography, as constituent units of DSE. He wanted an autonomous Institution and established the Institute of Economic Growth (IEG) by transferring some of the applied economics units from DSE, with himself as its first Director.

\footnotetext{
1 See K.L. Krishna (2017) "The Saga of the Delhi School of Economics- A Sketch" in Uma Kapila (Ed.) India's Economy: Pre-liberalisation to GST: Essays in Honour of Raj Kapila, New Delhi: Academic Foundation.
} 
Physically, IEG is adjacent to DSE, with considerable academic interaction ever since.

When C D Deshmukh became the VC of Delhi University in 1962, he persuaded Prof Ganguly to be the Pro VC. and K N Raj became the Director of DSE. This is a major event in the history of DSE.

\section{Progress Towards Academic Excellence: 1962-1971}

Prof Raj was the Head of the Department of Economics during 1962-1968, and the Director of DSE during 1962-1965. Under Raj's young and dynamic leadership, the faculty resources got considerably strengthened, paving the way for restructuring of the courses and revamping of the Ph.D. Programme.

Prof Amartya Sen joined the School in March 1963 as Professor of Economic Theory, the post vacated by Prof Rao. With the appointment of Prof Sukhamoy Chakravarty as Professor of Mathematical Economics, Prof Jagdish Bhagwati as Professor of International Trade, Dr Tapan Raychaudhuri as Reader in Economic History, and Dr A L Nagar as Reader in Econometrics, the Department of Economics got considerably strengthened in the mid-60 s. The MA program in Economics was restructured and modernized, and the Ph.D. programme was revamped and reactivated. The high standards of teaching and research achieved after mid-sixties drew worldwide recognition. The School attracted bright students from all parts of India. This was the 'glorious' era for the department of economics.

When Prof Bhagwati left for MIT in1968, Dr Manmohan Singh was invited as professor of International Trade. However, in 1970, he moved to the Ministry of Commerce, Government of India.The circumstances at the University level induced Prof Raj to accept its VC-ship in 1969. He tried to introduce several institutional reforms in 1969-1970. When he faced stiff resistance in the decision making bodies of the University, he resigned in disgust in1970 and returned to the School. In 1971, he accepted the Directorship of the Centre for Development Studies, Trivandrum, founded with support from the Government of Kerala.

The departure of Bhagwati in 1968, Tapan Raychaudhuri in1969, Manmohan Singh in 1970, and Amartya Sen and Raj in 1971, from the School to take up positions elsewhere has been referred to as an Exodus. The next section describes how the void was filled and academic standards were maintained.

\section{Teaching and Research Activity Sustained Despite Exodus: (1971-1992)}

The continuation of Prof Sukhamoy Chakravarty, Prof A L Nagar, Prof Mrinal Datta Chaudhuri, the arrival Prof Prasnta Pattanaik from Oxford in1971, Prof Pranab Bardhan from ISI, Delhi, the return of Dr V Pandit, from the University of Pennsylvania in 1971, the appointment of Dr Kaushik Basu, and Dr Pulin Nayak as Readers, Prof Raj Krishna as Professor helped the department. Former Ph.D. students, Om Prakash, Sundaram, Krishnamurty, Balvir Singh, Bhaskar Dutta, Aman Ullah and Ashok Lahiri too helped the Department in teaching-arrangements. In 1978, Prof Suresh Tendulkar was invited from ISI Delhi, as Professor in the department. 
In my assessment, although the Department suffered a great loss due to the adverse effects of the exodus, remedial steps were taken to minimize the loss. The teaching standards in the department continued to be one of the best in the country. The leadership provided by the senior professors and their continuation is indeed laudable. Prof AL Nagar was among them. The School's academic activities during this period are covered in Raj (1995) Sen (1995), Nagar (1995), Lahiri (1995). Datta Chaudhuri (1995), Pattanaik (1995), and Basu (1995) also have important material.

\section{Post 1992 Period-CDE Established for the Rejuvenation of the Department.}

Centre for Development Economics (CDE) founded in August 1992 owes a great deal to the imagination and initiative of Prof Kaushik Basu. Funding came from the Ministry of Finance, Government of India and Ford Foundation for promoting fundamental and policy research in economics. Annual Winter School, where outstanding economists lecture on recent advances in major fields of economics has become a regular feature. Research infrastructure, including computing and communications improved. Krishna (2017) has more details about the contribution of CDE to the process of rejuvenation in the department.

As a result of the advent of CDE, the Department continued to be active in the closing decade of the twentieth century and the beginning of the twenty-first century. However, with the explosive increase in student enrolment as per the government policy and delay in filling faculty vacancies, it has become difficult to maintain academic standards.

\section{A L Nagar (1995): My Experiences at the Delhi School of Economics}

A L Nagar (1995): 'My Experiences at the Delhi School of Economics' is a very valuable account of how the Department of Economics at DSE functioned during his service there from 1963 to 1995, when he retired from Delhi University. He summarized his experiences as follows:

"In retrospect, it has been a fruitful experience for me at the DSE both in terms of my teaching and research experience. The DSE has been successful in attracting good students from all over the country. I succeeded in building up a fairly good group of students for research in econometrics. Some of them now occupy top positions in the profession and their contributions are widely published and well known in the literature. The interaction with students and faculty members has been rewarding indeed. Timely revision, the updating of courses and an improvement in computing facilities over the last three decades have helped a great deal in raising the standards of teaching and the quality and quantity of research output within the department".

The department provided for two sets of optionals in Econometrics, one for those students who were mainly interested in applications of econometrics and the other for those who were interested in theoretical foundations of econometrics. "Whereas the applied econometrics (optional group L) was the most popular of optional 
courses, the theoretical econometrics (optional group E) attracted devoted students. Students from both these groups have done exceedingly well in their research studies."

The number of Ph.D. students on the rolls increased substantially during 1965-1975. Five to six students got their Ph.D. degree every year. About 20 of the Ph.D. students worked with Prof Nagar, and an equal number with Prof Krishna and Prof V. Pandit. Some of Nagar's students worked on applied problems. A major theme of research in theoretical econometrics was the estimation of parameters in simultaneous equation models. Nagar mentions his papers in Econometrica, 1959 and 1960 which had attracted world-wide attention. These were the first studies in the field, providing small sample properties of estimators. Aman Ullah's exact sample results were published in Econometrica 1974. N C Kakwani worked on the use of prior information in the estimation of regression and simultaneous equation models. Nagar refers to work of R.N. Lal and Ashok Lahiri on applied problems.

According to Nagar, the sixties and seventies saw a lot of enthusiasm in research in econometrics. The introduction of the M.Phil program in 1976 had an adverse impact on Ph.D. admissions, with candidates preferring the M.Phil programme which took much less time to complete. The enrolment in M Phil was restricted to 20. Only two to four students per year are admitted to the Ph.D. program in later periods.

\section{Ashok Lahiri (1995) on Econometrics at the DSE in the 1960s and 1970 s.}

The econometricians at the School- in particular Professors Nagar and Krishnaand Prof Pattanaik on economic theory, Prof Pranab Bardhan on international trade, and Prof Raj Krishna on Agriculture had distinctive styles of teaching. Drs. R K Das, V Pandit, Balvir Singh, and Aman Ullah, apart from Krishna and Nagar used to teach optional group E courses. Balvir Singh and Aman Ullah were Nagar's Ph.D. students. From the late $60 \mathrm{~s}$ through the $70 \mathrm{~s}$, DSE had a flourishing doctoral program. Among the brilliant Ph.Ds, there were quite a few econometricians.

The econometrics research at the School was either theoretical or empirical. In the late $50 \mathrm{~s}$, Nagar had done some path-breaking work in finite sample econometric theory through his asymptotic expansion- Nagar's large-T approximation of the moments of the K-class estimators in the simultaneous equation model. He continued his work in association with his students resulting in contributions to the literature on finite sample econometrics comparable to that of Prof Sargan and his students at the LSE. Nagar and his students, notably Nanak Kakwani, Balvir Singh, and Aman Ullah produced some fundamental papers on bias of moment matrices of mixed regression estimators, Econometrica, 1964, SURE (JASA1974), properties of 2SLS estimators Econometrica, 1974 and random coefficient estimators (International Economic Review 1976).

Under Nagar's supervision, some important empirical work was done on National Accounts, Capital Formation, Income Distribution, the effects of modern technology on economic efficiency in the Agriculture Sector. The School had access to IBM 
1620 and IBM 360 systems at that time, before the advent of PCs. The School had set the standard for quality empirical work and contributed significantly to the future growth of solid applied econometrics in the country. It merits mentioning that Ashok Lahiri researched on the demand for money during 1973-76 under Prof Nagar. He later blossomed as a distinguished macroeconomist, his most recent position being membership of the $15^{\text {th }}$ Finance Commission of the Government of India.

\section{Nanak Kakwani-Prof Nagar's first doctoral student}

Prof Nanak Kakwani became Prof Nagar's first doctoral student in IIT Kanpur in 1962, after completing his Master's degree in Statistics in Delhi University. He migrated to DSE in 1963 along with his Guru. He obtained his Ph.D. degree from Delhi University in 1965 on Mixed Regression Estimators. He published 5 papers with Prof Nagar in international journals. Much of his later work was on themes like Poverty, Inequality. Pro-Poor Growth, and Welfare Measurement. Kakwani is very proud of being Nagar's student. He says that he learned from Prof Nagar in mid-sixties as to how to do research. Kakwani made a distinct mark as a development economist. He was Professor in Econometrics in the University of New South Wales, Sydney, Australia, from 1970 to 2000 . He is still an active researcher in Development Economics, with pronounced quantitative orientation.

\section{Prof Nagar's Research and Teaching Activity at JNU, NIPFP and ISPE after Retirement}

Prof Nagar retired from DSE, Delhi University in 1995. Between 1995 and 2011, he was associated with NIPFP, New Delhi, and CITD (Centre for International Trade and Development) at JNU. At CITD, he used to teach the second year optional course in Econometrics. For research, he collaborated with Prof Amit Shovan Ray and Dr Aparna Sawhney and they published a paper on the Interface of Income, Health, Life Expectancy and Environment: an Econometric Investigation. The paper estimated a structural model using data for 25 years; it was published in the Journal of the Indian School of Political Economy, Pune, a few months before Prof Nagar's demise.

In the four-equation structural model Y (GDP per capita), life expectancy (LP), Health $(\mathrm{H})$ and PM10 (respirable particulate matter) are the endogenous variables. The important exogenous variables are physical infrastructure and social infrastructure. The equations in log linear form were estimated by 2SLS using data for 25 years, 1980-81 to 2004-05, for the Indian economy.

Two important findings of the study are: first, the respirable particulate pollution has high cost on income and health. A one percent increase in air pollution leads to a decrease of 8 percent per capita income and a decrease of 0.7 percent in life expectancy and an increase of 19 percent in the number of cases of respiratory diseases. 
Social infrastructure plays a more vital role in development than physical infrastructure. There is need to pay more attention to providing social infrastructure and reducing particulate pollution.

Although static and simple, the estimated model provides useful insights about the nature of economic development in India. It is indeed a pioneering study in terms of methodology and social relevance.

At NIPFP, Prof Nagar collaborated with Mr Sanjay Kumar, an officer of the Indian Revenue Service. They were assisted by Sayan Samanta to study the Effectiveness of Tax Administration. Their paper, Índexing the Effectiveness of Tax Administration' was published in the Economic and Political Weekly, December 15-22, 2007.The paper develops an econometric model using principal components. The results show that there has not been much change in the effectiveness of direct tax administration over time. The policy implication is to strengthen the tax administration.

Prof Nagar and Mrs Nagar shifted to Pune in 2011 to be with their son. Prof Nagar was a Visiting Fellow at the Indian School of Political Economy, Pune, from 2011 till his demise in 2014.He and Prof Chitre of ISPE were contemplating joint econometric work, following a methodological suggestion of Prof Nagar. Tragically, Prof Nagar passed away before the study could be started (Chitre 2014). Professor Nagar was developing new ideas of research till the very end. His death came too soon.

\section{Concluding Remarks}

I had the good fortune of being Prof Nagar's junior colleague in DSE for several decades. I was the Founding Managing Editor of JQE for ten years, 1984-1994. He was the Editorin-Chief from 1984 until his death in 2014. I received valuable advice and guidance from him. The initial success of JQE was due to good understanding between us. We had the benefit of Kaushik Basu's association as Joint Managing Editor. I am grateful to the Editors of the Special Issue of JQE for asking me to contribute an Introduction. I have tried my best to produce this introduction.

Prof A L Nagar was a very distinguished econometrician, who produced an excellent thesis under the supervision of Prof Henry Theil, another distinguished econometrician. The DSE enjoyed the privilege of Prof Nagar's association from 1963. Prof Nagar held many positions, including the Pro-Vice Chancellorship of Delhi University. He commanded much respect in all the positions held.

Prof Nagar was a highly gifted teacher. He supervised large number of theses, both in theoretical and applied econometrics. Many of his students have brought much credit to DSE and India. He was a veritable source of inspiration to the student community and junior colleagues. He left a very rich legacy of scholarship.

Acknowledgements I wish to thank Prof. Aman Ullah for valuable suggestions on the draft of the essay. I received much help from Dr R. Rijesh and Dr. A. Sri Hari Naidu for help in the processing of the essay. 


\section{References}

Basu, K. 1995. From a personal point of view, in Kumar and Mookherjee (eds.)

Carter, R.A.L., J. Dutta, and A. Ullah. 1990. Contributions to econometric theory and applications: essays in honour of A.L. Nagar. Springer.

Chitre, V. 2014. Obituary: A.L.Nagar. Journal of Indian School of Political Economy 26

Datta Chaudhuri, M. 1995. The school and i, in kumar and mookherjee (eds.)

Dhar, P.N. 1995. The early years, in kumar and mookherjee (eds.)

Goldberger, A.S., Nagar, A.L., Odeh, H.S. 1962. The covariance matrices of reduced form coefficients and forecasts for a structural econometric model. Econometrica 29

Kakwani, N.C. 1965. Note on the unbiased estimation of the third moment of the residual in regression analysis. Econometrica 33: 434-436.

Kakwani, N.C. 1967. The unbiasedness of Zellner's SURE estimators. JASA 62: 141-142.

Kakwani, N.C. 1968. Note on the unbiasedness of a mixed regression estimator. Econometrica 36: 610-611.

Krishna, K.L. 2017. The saga of the Delhi school of economics- A Sketch, in Kapila, U. Indian economy since liberalisation to GST. Academic foundation.

Krishna, K.L. in V.N., Balasubramanyam. 2001 Conversations with Indian Economists, Palgrave.

Kumar, D., and D. Mookherjee. 1995. D school: reflections on the Delhi school of economics. OUP.

Kumar, S., Nagar, A.L. and S. Samanta. 2007. Indexing the effectiveness of tax administration. EPW 50: $104-110$.

Lahiri, A. 1995. Econometrics at the DSE in the 1960s and 1970s in Kumar, D. and Mookherjee, D., D. School

Nagar, A.L. 1959. The bias and moment matrix of the general k-class estimators of the parameters in simultaneous equations. Econometrica 27: 575-595.

Nagar, A.L. 1960. A Monte Carlo study of alternative simultaneous equation estimators. Econometrica, July

Nagar, A.L. 1962. Double k-class estimators of parameters in simultaneous equations and their small sample properties. International Economic Review 3: 168-188.

Nagar, A.L and N.C. Kakawani. 1966. Note on the bias of a mixed simultaneous equation estimator. International Economic Review 7:65-71.

Nagar, A.L. 1995. My experiences at the Delhi school of economics in Kumar, D. and Mookherjee. D. School: reflections on the Delhi school of economics. OUP.

Nagar, A.L., and N.C. Kakwani. 1964. The bias and moment matrix of mixed regression estimator. Econometrica 32: 174-182.

Nagar, A.L., A.S. Ray, A. Sawhney, and S. Samanta. 2013. Interface of income, health and environment: an econometric investigation. Journal of Indian School of Political Economy 24: 13-32.

Pandit, V. 2014 Obituary, A.L.Nagar. EPW

Pattanaik, P.K. 1995 My years in 'the school' in Kumar and Mookherjee (eds.)

Raj, K.N. 1995 The Delhi school of economics, in Kumar and Mookherjee (eds.)

Rao, S.L. 2012 V.K.R.V., Rao in K. Basu, A. Maertens (eds) The New Oxford Companion to Economics in India. OUP.

Sargan, J.D. 1974. the validity of Nagar's expansion for the moments of econometric estimators. Econometrica 42: 169-176.

Sen, A. 1995. The Delhi school of economics, in Kumar and Mookherjee (eds.)

Theil, H. 1971. Principles of econometrics. John Wiley.

Theil, H., and A.L. Nagar. 1961. Testing the independence of regression disturbances. JASA 56: 793-806.

Ullah, A. 2004. Finite sample econometrics. OUP.

Ullah, A. 2014. Obituary, A.L.Nagar, 1930-2014. Journal of Quantitative Economics

Publisher's Note Springer Nature remains neutral with regard to jurisdictional claims in published maps and institutional affiliations. 